\title{
Aleksander Ford and Film Censorship in Poland
}

\author{
By Anna Misiak \\ Fall 2003 Issue of KINEMA \section{SHIP IN POLAND AFTER 1945} \\ POLITICALLY INVOLVED FILMMAKER: ALEKSANDER FORD AND FILM CENSOR-
}

AFTER World War II civil rights were restricted in Poland as in most of the countries that fell into the zone of Soviet influence. Polish citizens experienced censorship in almost every field of their daily existence. Within the film industry censorship did not function solely as a means of checking final products from the standpoint of ideology. The controlling machine was not only the domain of the Party itself, even though its officials held decisive voice in restricting the autonomy of artists. The highly elaborate system also involved many moviemakers, who often proved to be very efficient in establishing methods of censorship and propaganda within Polish cinema. There was no clear-cut division between the Party and the filmmakers. Both groups became mixed, and the latter often willingly cooperated with the first.

Just after the war there was actually one person, a war survivor, who took over the Polish film industry, and at the beginning almost all of the film content control rested in his hands. Surprisingly enough it was not a Party official, but a professional film director named Aleksander Ford. He did not act alone; accompanied by many of his prewar coworkers, who were affiliated with the Party, he rebuilt most of the production infrastructure after 1945. While discussing this group of Polish cinema founders Roman Polanski concluded in his biography,

They included some extremely competent people, notably Aleksander Ford, a veteran party member, who was then an orthodox Stalinist.(...) The real power broker during the immediate postwar period was Ford himself, who established a small film empire of his own. ${ }^{(1)}$

As Ford identified himself as a Communist, he tried to carry into effect his vision of filmmaking for the public good. Even though he never fully succeeded, his actions resulted in generating a complex system of cinema control, which was present in Poland, with slight modifications, almost until the end of 1980s.

Ford's affiliation with the Communist Party came to an end in 1968. Nevertheless, he was no mere victim of the political system. In 1945 his position had been extremely strong. While the industry was recovering from the war he had belonged to the group of decision makers. Nobody thought then that he would become a victim of the system he himself had helped to create.

\section{To the top}

Let us move back in time and recall some prewar experience of the director, as his career before 1939 had a great impact on his postwar political involvement. The ideological attitude that had been shaped in his youth seriously contributed to the vision of movie production he implemented.

No doubt the most outstanding of his prewar output was the 1932 feature Legion ulicy, (The Street Legion, 1932). This was the film that actually set the direction for his further artistic development. It also earned him his first award: the gold medal of Kino magazine. Critics called it the best movie of the year. Asked how he achieved such a great success, he usually pointed out the social involvement of his movie, and replied, "Cinema cannot be a cabaret, it must be a school." This confidence in the educational role of movies and its ability to express social messages on the screen was visible in all of his subsequent moves, not only as a director, but as the founder of Polish film industry as well. He started his career from the leftist and Communist film and stayed there.

In 1929 in Warsaw the influential group of film makers and theorists was first formed. It was called START (Stowarzyszenie Milosnikow Filmu Artystycznego: Society of the Devotees of the Artistic Film). As a young

Marxist Ford wanted to challenge the commercial cinema. Being a START member he convinced himself that the movies should spread didactic messages and he tried to propagate this point of view after 1945. 
Ford spent the war in the Soviet Union. He refused enlistment under General Anders who supported the Western Allies and driven by his ideological background in 1943 he joined the Polish unit of Red Army formed under Soviet supervision in Russia. The military order by General Zhukov laid the foundation for a crew of army filmmakers who were to make documentaries on the Soviet and Polish joint military success. Ford was in charge of the Polish Army Film Command called Czolowka. He was appointed by the commander in chief on July 16, 1943.

It is not clear why it was Ford who was chosen to be the head of film production for the army. One possible and most reasonable explanation could have been his prewar achievement in filmmaking, but most probably it was his political and ideological engagement, which was the decisive factor. Other prewar Polish film directors cooperated with Ford under military rule. They possessed just one camera, but worked very fruitfully and completed quite a few documentaries together.

The army financial support made filmmaking for Ford a much easier task than what he was used to. He remembered well his prewar financial struggles; he realized how hard it was to gain money for film productions. The filmmakers linked to the army often discussed the future shape of Polish film industry. As the soldiers moved closer toward victory, Ford knew that the financial aspect of a moviemaker's existence could be again the hardest one.

Even before the first piece of land in Poland was liberated, the army filmmakers had made their minds. They were in favour of a cooperative solution. "The opening titles of the film titled Majdanek (1944) made during the Lublin period can be seen as an echo of those early cooperative speculations. They stated that the producer of the moving documentary was Polish Film Cooperative." ${ }^{(2)}$ Ford was one of the supporters of the social film industry idea, which he inherited from his prewar days. The pattern of the planned cooperative was derived from the Cooperative of Film Authors, which was established as the START initiative in 1937.

In 1944 the new authorities in Poland launched their project of rebuilding the country's film industry. They recognized socially and ideologically engaged films as useful tools of persuasion and propaganda in the newly established political system. Besides, nationalization of the media made control simpler and more efficient. The government Department of Information and Propaganda was formed in July 1944. It consisted of seven units dealing with different media. Aleksander Ford was in charge of the Film Division. According to its founding act the Film Division was responsible for movie theatres, film distribution, promotion of culture and education by the means of film and most of all it was an institution obliged to rebuild the film industry that was ruined. ${ }^{(3)}$ A year later the Department became a Ministry and the Film Division was renamed Department of Film Propaganda.

Political changes defined the model of the new film industry. It had to go along with the socialist character of the economy. Thus, nationalization became a politically dictated necessity. Obeying the will of politicians in power Ford gave up his idea of a cooperative. One day Ford, mysterious as usual, told his colleagues that he just had had a conversation and that film industry would be state owned. As to the questions "Whom did you talk to?" he replied "To whom I needed to!"(4)

The first target of nationalization was the theatres. Step by step the theatres were taken over by the government officials and film industry people, until finally all of the Polish movie houses were nationalized. Taking over the theatres was part of the implementation of Ford's vision. The concentration of production and distribution means in one hand allowed the thorough control of film distribution. It assured that the approved productions would be exhibited, but the most important reason of Ford's support for this action was that ownership of the movie theatres and screening rooms guaranteed the abolishment of any possible competitors.

In November 1945 Ford became the director of the fully nationalized state production company Film Polski, which in fact replaced the earlier Department of Film Propaganda. This consolidated entity was given full monopoly in production, distribution and exhibition of movies in Poland.

Ford was interested in rebuilding the film industry regardless of the costs. On January 19, 1945 the Central Office of Control was established and then renamed the Main Office for Control of Press Publications and Public Performances. Ford was probably aware what institutionalized censorship meant for the filmmakers, but convinced it was politically just he supported this institution. As the head of Film Polski he was obliged 
to set up internal forms of censorship, controlling all the stages of filmmaking, starting from script writing. Being part of the political elite of the time he performed the same actions as most of the politicians, and he himself tried to limit the creative freedom of other film artists.

The first censored movie in postwar Poland was $2 x 2=4$ (1945) directed by Antoni Bohdziewicz. He made his film in cooperation with young people from his Youth Film Workshop based in Cracow. In May 1945 this production was banned from distribution by the Office of Control. It is not clear to what degree this decision had to do with the content of the film, and to the personal influence of Ford who did not appreciate Bohdziewicz because of his previous political rightist affiliation. Not only did Ford disregard the film, but he also closed down the Workshop and decided that some other more lenient directors should take over the education of the next generation of filmmakers. He even provided the fully written schedule for the new workshop.

Ford wanted full control. He could not stand either competition or opinions that did not approve his actions. Why? One of the Polish researchers on the subject, Edward Zajicek, answers the question, "It is not impossible, as some of his antagonists stated, that he was afraid of the risk that new talents would appear who would be much better than the old masters." (5)

The conflict with the people from Cracow had its climax in 1946, when Bohdziewicz wrote to Ford,

You are a bad director of this enterprise and it cannot be hidden any longer. Aleksander, please believe me your closest colleagues are of the same opinion, denying it won't help you much, I know it is true and I am courageous enough to tell you as it must be said. As we know (...) you have no management or organizational skills, you are inconstant, capricious, and irresolute, you are driven by illusion (that everything is fine) and very often you take fiction for reality... ${ }^{(6)}$

The following two years proved Ford could not manage the film industry. Despite the close supervision of films and scripts he was accused of allowing many ideological mistakes. The system of control he had been obliged to create was supposed to eliminate anything that was not appropriate for screen presentation, and Communist officials should not have found any problematic issues. It did not work. Ford was accused of not encouraging writers to promote socialism.

The script problem spoiled Ford's reputation; in addition, he failed in other areas. Instead of the planned several thousand movie theatres in 1947 there were only 516 in the country. Moreover, the audience complained about the quality of film prints and the repertoire that contained mostly Soviet productions. Soon another problem emerged. Ford was accused of financial corruption within the state enterprise.

As a result of widespread criticism Ford was replaced, and the party official Stanislav Albrecht became the new director of Film Polski. Ford was fired due to his poor cooperation with the Party officials during the last year of his film industry supervision, and also because he failed to set up stricter internal film content control. The Political Bureau of the Communist Party supported most of the new director's moves. He used political police methods while managing the film industry, but it was exactly what he was expected to do.

Albrecht was able to find fault with all the steps taken by his predecessor. His objections did not relate solely to Ford's methods of handling the job. He also negatively evaluated Ford's ideological attitude and his artistic achievement.

Having lost his position in 1947, the offended Ford went to Prague in Czechoslovakia, where he worked on his first feature production in the postwar period, titled Ulica graniczna (That Others May Live/Border Street, 1948). Before leaving the country, he did not present the script to the new industry management. Obviously, it was an act of insubordination performed in defiance of Albrecht's authority. Even though Ford tried very hard to avoid supervision Albrecht personally came to Prague to check the movie in making. He was of the opinion that the movie about Jewish tragedy in the Warsaw ghetto should never enter Polish theatres. Ford was forced to modify his production but this did not help much. Even though Border Street obtained permission for distribution, opponents accused the film director of neglecting socialist ideology. Similar objections to Ford's new production appeared during the Congress of Filmmakers in Wisla in 1949, where the high-ranking political leaders instituted "socialist realism" as the leading filmmaking style. There Ford was accused of offending Polish national feelings. He tried to defend himself, but his effort was useless. 
The trouble with Border Street did not mean that all of a sudden Ford had moved to the opposition and had started to support political adversaries of the system. He had simply failed to perform as well as the Communists at the top expected him to. Ford liked to be in power and he was willing to do anything to regain his previous position. As a great conformist and opportunist he decided to comply with the new politically trendy "socialist realism" in order to make up for his previous failure. More or less at that time, he started to compete against Albrecht and they both fought each other in order to gain higher positions in the industry's Party ranks.

On December 15, 1951, Film Polski became the Central Office of Cinematography. Albrecht had made his vision come true. The film industry was managed at the central level. The Central Office, which began an even stricter control of filmmaking, became active in January 1952. Incidently, it was quite a paradoxical year: the controlling machine went into effect at the year's beginning while the new Constitution guaranteeing freedom of speech in Article 83 was passed in July.

At about this time Ford completed his "socialist-realist" movie Mlodosc Chopina (The Youth of Chopin, 1952) where he implemented all the party prescriptions from the congress in Wisla. The biography of the Polish piano composer was reduced to an image of the "friend of working classes." Distribution started in 1952. This movie was highly esteemed by Party officials and was held up as a model film during the Filmmakers' Meeting in March 1952. One of the Party officials named Edward Ochab stated that the new production by Ford marked a serious achievement of the Polish film industry in praising socialism. By conforming to the Party requirements while making The Youth of Chopin Ford clearly found his way back to the top. He was again one of the country's most respected movie directors.

From 1952, Alexander Ford was again among the leading industry people. The party officials appointed him as a member of many industry decision-making bodies. At some point he even found himself overworked. In 1954 during the meeting of Commission for Evaluating Scripts and Films he stated,

I have to admit that I cannot envision a possibility of rethinking this scenario (...). How could one do it in my situation? On Tuesday I have some meeting of Polish Association of Theatre and Film Artists, on Wednesday - today - the meeting of the Commission for Evaluation, on Thursday I have another Commission and the reunion of Film School alumni, on Friday Artistic Counsel, on Saturday I teach at School. I would like to point out that this is not some exceptional schedule. ${ }^{(7)}$

Attending all the most important commissions was a clear sign of his rehabilitation by the Party. He was seen as a good Communist again. It took great conformity on his part and sacrifice of personal vision. But he had again found his cozy room at the top.

As a member of the Commission for Evaluating Scripts and Films Ford could meet his opponent Albrecht face to face. Most often in his speeches he undermined the ideological approach of his opponent. Albrecht wanted to spread the illusion of the Commission as the decisive body which approved scripts for film production. Ford tried to abolish it by saying,

It is often that the Commission talks about some script in negative terms, and nevertheless Film Polski starts production. I forbid one thing - the Commission criticizes here rightly or not, but we never expect that this Commission will dictate changes. ${ }^{(8)}$

Ford was not in favour of the iron hand that Albrecht used in managing the film industry. Even though he supported state control he usually meant it to smaller degree.

When all of a sudden the political freeze ended with the death of Josef Stalin and Khrushchev's denunciation of the personality cult, the first signs of relaxation appeared in Poland. It ultimately changed the situation of the filmmakers. As te old structures started to crumble, Ford saw his chance. In 1955 his conflict with Albrecht eventually ended altogether with the removal of the head of Central Office from his post. However, Ford hated him so much that post factum he caused liquidation of the Central Office which his opponent had regarded as his life-time achievement. The film industry lost its central status and Ford finally managed to win and gain his previous position. Nevertheless, it soon turned out to be a Pyrrhic victory. Those in favour with the authorities today could find themselves out of favour the next day. Each step taken by an 
artist or an entertainer was closely watched and noted by the authorities.

\section{The fall}

In 1980 in Florida, Aleksander Ford, who was then well known in his country as the director of the Polish blockbuster Krzyzacy (Knights of the Teutonic Order, 1960) committed suicide. In March 1969 he was forced to leave Poland as a victim of an anti-Semitic campaign initiated by the First Party Secretary Wladyslaw Gomulka. More or less a year before, he had fallen into disgrace as he refused to state publicly his ideological mistakes and express self-criticism. On April 30, 1968 party leaders arrived at the Filmmakers' union meeting and dismissed all the people who were in charge of film production units which had been present in Poland since the 1956 "Polish October." Ford was among the fired directors. The Polish-West German co-productions were also heavily criticized as politically incorrect. Two such films, severely treated by censors, were pointed out. These were Rassenschande: When Love Was a Crime (Kiedy milosc byla zbrodnia, 1967) directed by Jan Rybkowski and Eighth Day of the Week (Osmy dzien tygodnia, 1958) by Aleksander Ford.

In the 1950s and 1960s it was very rare that a movie became the subject of scrutiny by the Main Office of Control. As Zygmunt Machwitz noticed, on Mysia Street (the street in Warsaw where the Main Office of Control was located) the filmmakers were given only seals of approval necessary to start distribution. ${ }^{(9)}$ After the "Polish October" all of the filmmaking control was handed over to the Commission for Evaluating Scripts and Films under the film industry and Party supervision. Just before 1968 the Commission was closed down, while the film units themselves were responsible for controlling the content of their productions. Their actions were obviously supervised by Party officials that had to be employed on separate basis in every unit. Anything that had been overseen in earlier stages was corrected during the final pre-distribution screening for industry people and party delegates which was known as kolaudacja. Therefore, government authorities and the proper censors had to pass judgment on very few movies.

In 1968, When Love Was a Crime was banned even though it had been approved for distribution before. As the political conditions changed due to the war in Israel, any connection with Western democracies brought up charges of popularizing antisocialist ideology. Rybkowski surrendered under pressure and together with three other movie directors made his public self-criticism.

Ford did not comply and refused any charges of antisocialism related to his production Eighth Day of the Week. It was a 1958 production which had never been exhibited. (It is worth mentioning that wide distribution of the film was not allowed until 1983, three years after the director's death. ${ }^{(10)}$ From the very beginning of production the film was fated to struggle with censors. A major reason was the fast that the scriptwriter Marek Hlasko was an author disapproved of by the Party for presenting a dark vision of Polish reality which went against the dominant ideology. Being an especially controversial film, Eighth Day of the Week had already been screened for Party leader Wladyslaw Gomulka in 1958 but he had halted the projection and had left the room cursing not only Ford but all other Polish movie makers. This resulted in the film's distribution ban.

In 1968 the Party reminded itself of this controversial production, and accused Ford of antisocialist activity for working on it in Federal German Republic ten years before. He did not feel guilty and did not humble himself. His resistance resulted in an expulsion from the Communist Party. In December 1968 his film unit Studio was liquidated by the authorities. As a film director who was not engaged ideologically he did not have any opportunity to be employed in the film industry. He lost his position for good. As with most of the Jews at the time he was forced to leave the country and headed for Israel. Later on he tried to find opportunities in other countries. However, he never managed to recover from his loss of home and emigration ended tragically for him.

After 1969 Ford's name ceased to exist not only in contemporary production but also in the historical analysis of Polish filmmaking. It was not supposed to be even mentioned. In The Black Book of Polish Censorship, which used to be the basic list of prescriptions for censors in Poland in 1970s, Ford was among other banned names. The chapter titled "Culture" of this publication stated, "As to the persons listed below the rule of elimination of their names and any reference to their output from press, radio and television, as well as non-academic publications should be applied."(11) (Aleksander Ford appears as the fifth name from the top of the list.) 


\section{Conclusion}

Communism in Poland was founded on its dependence on the Soviet Union. Even though the Party officials attempted to control all the spheres of life, they had to modify their principles according to the political changes in its Eastern neighbour state. As such, staying at the top was almost impossible, as one's position depended on the political winds of change. According to film historian Frank Bern, "it was impossible to be a good Communist in one shade of red for more than a few years in stretch."(12)

Polish film director Andrzej Munk made a brilliant parody of that reality which promoted rather opportunism than stable political devotion. His conformist character named Piszczyk tries to be politically in tune, but he always finds himself on the opposite side from what he had initially planned. This movie was produced at the end of 1950s and is titled Zezowate szczescie (Bad Luck, 1960). The political swings in Poland under Communist rule were often faster than any opportunist could follow. Today, twenty years after Ford's suicide we can compare him to this movie character. Having identified himself as a Communist, he used the whole range of opportunities to get to the top. But there is also a crucial difference: he reached the point when the twist in ideology was too much and he resisted the final call for extreme opportunism. Eventually he was

rejected and expelled from the system he had co-built himself. It was one more among the many paradoxes of Communism in Poland. Politically controlled film industry in its great reliance on the Party officials excluded its founder and devoted supporter Aleksander Ford. His search for identity as a Communist filmmaker came to a tragic end.

\section{Notes}

1. Roman Polanski, Roman (New York: William Morrow and Company, Inc., 1984), 104.

2. Edward Zajicek, "Aleksander Ford - organizator kinematografii", Miesiecznik literacki, No. 2 (1985): 65.

3. Daria Nalecz, Wstep, in Dokumenty do dziejów PRL: Glówny Urzad Kontroli Prasy 1945-1949, ed. by Daria Nalecz (Warszawa: Instytut Studiów Politycznych Polskiej Akademii Nauk, 1994), 11.

4. Edward Zajicek, "Aleksander Ford - organizator kinematografii", Miesiecznik literacki, No. 2 (1985): 65.

5. Zajicek, "Aleksander Ford - organizator kinematografii", 69.

6. Quoted from Jan Lewandowski, "Obrachunki Fordowskie", Film Magazyn Ilustrowany, No. 6, (5 lutego 1984): 11.

7. Protokol z posiedzenia Komisji Ocen Filmow i Scenariuszy, 20 pazdziernika 1954, Archive of National Film Library in Warsaw, No. A-214, pos. 38.

8. Protokol z posiedzenia Komisji Ocen Filmow i Scenariuszy z dn. 28 pazdziernika 1953, Archive of National Film Library in Warsaw, No. A-214, pos. 25.

9. Zygmunt Machwitz, "Represje i opresje w kinematografii PRL", Tygiel kultury, No.1 (1996): 95.

10. The first public screening took place in June 1981.

11. Czarna ksiega cenzury PRL, Vol. 1 ( Londyn: Aneks, 1977), 54-55.

12. Frank Bern, Poland, World Cinema 1, rev. edition (Wiltshire, BA, Flicks Books, 1990), 47.

\section{References}

\section{Bibliography}

Bern, Frank. World Cinema 1: Poland. Revised edition. Wiltshire, BA: Flicks Books, 1990.

Contemporary Polish Cinematography, Warsaw: Polonia Publishing House, 1992.

Czarna ksiega cenzury PRL. Vol.1. London: Aneks, 1977. 
Głębicka, Ewa. "Kinofikacja czy kinofikcja lata 1944-47." Iluzjon no. 3-4. (1993): 39-45.

Hendrykowska, Małgorzata. Kronika kinematografii polskiej 1895-1997. Poznań: Ars Nova, 1999.

Janicki, Stanisław. Aleksander Ford. Warszawa: Wydawnictwa Artystyczne I Filmowe, 1967.

Lewandowski, Jan F. "Obrachunki Fordowskie." Film Magazyn Ilustrowany, no. 6 (1984): 11-12.

Machwitz, Zygmunt. "Represje I opresje w kinematografii PRL." Tygiel Kultury, no. 1 (1996):94-100.

Madej, Alina. "Zjazd Filmowców w Wiśle, czyli dla każdego coś przykrego." Kwartalnik Filmowy, no. 18 (1997): 210- 214.

"On". Kwartalnik Filmowy, no. 6 (1994): 196-203.

Michalek, Boleslaw, and Frank Turaj. The Modern Cinema of Poland. Bloomington and Indianapolis: Indiana University Press, 1998.

Nalecz, Daria. Dokumenty do dziejów PRL. Główny Urzad Kontroli Prasy 1945-1949. Edited by Daria Nalecz. Warszawa: Instytut Studiow Politycznych Polskiej Akademii Nauk, 1994.

Polanski, Roman. Roman. New York: William Morrow and Company, Inc., 1984.

"Wielka gra: ze Stanislawem Albrechtem rozmawia Alina Madej." Kwartalnik filmowy, no. 6 (1994): 204-206.

Zajicek, Edward. „Aleksander Ford- organizator kinematografii”. Miesiecznik literacki, no.2 (1985): 63-73.

Poza ekranem: Kinematografia polska 1918-1991. Warszawa: Filmoteka Narodowa Wydawnictwa

Filmowe I Artystyczne,1992.

\section{Author Information}

Anna MISIAK is a Ph.D. candidate (Fulbright Grantee) at the School of Cinema-Television, University of Southern California, in Los Angeles. In Poland, she has taught at the American Studies Center, Warsaw University, while completing her studies at the Graduate School for Social Research, Polish Academy of Sciences, Warsaw. Her research work on Film Censorship and reviews have been published in Polish academic journals. 